\title{
Błażej SAJDUK
}

Uniwersytet Jagielloński w Krakowie

blazej.sajduk@uj.edu.pl

\section{PHILIP E. TETLOCK, DAN GARDNER, SUPERPROGNOZOWANIE. SZTUKA I NAUKA PROGNOZOWANIA}

\section{Przeł. Maciej Markiewicz, CeDeWu, Warszawa 2017, 335 s.}

Każdy z nas, kto korzysta ze środków masowej komunikacji, niejednokrotnie natknął się na program publicystyczny, w których osoba prowadząca próbowała wydobyć od zaproszonych ekspertów ich opinie na temat przyszłego rozwoju wypadków. Nieco przejaskrawiając, najczęściej w takiej sytuacji da się zaobserwować dwa rodzaje reakcji. Pierwsza to unik, zazwyczaj przez udzielenie odpowiedzi bardzo ogólnikowej, druga reakcja to całkowite uchylenie się od odpowiedzi. Można domniemywać, że tego rodzaju zachowanie wynika najczęściej z chęci zachowania twarzy przez ekspertów oraz jest podyktowane specyfiką świata nauk społecznych, którą na przykładzie nauk politycznych gorzko podsumował Jack Harward, pisząc: politolodzy mogą zaoferować: przyzwoite wyjaśnienia, ale już po fakcie, zrozumienie teraźniejszości oraz niemal żadnych przewidywañ ${ }^{1}$. W Polsce silne wydaje się przekonanie Jarosława Bartkiewicza, że formutowanie zdań predykatywnych w rodzaju: "to coś wydarzy się wtedy" nie należy do sfery prognostyki, lecz profetyki (czyli wróżbiarstwa). Prognozowanie wiarygodne, czyli dokonywane na poziomie teoriohistorycznym, wprowadza taki stopień ogólności, w którym raczej jawia się zarysy $i$ kontury każace się bardziej domyślać ksztattów przysztości, niż wyrokować o faktograficznym ksztatcie przysztości $i^{2}$.

I choć oczywiście świat medialny rządzi się swoimi prawami, to jednak zdaniem Philipa E. Tetlocka, badacza zajmującego się procesem formułowania prognoz oraz współautora (obok Dana Gardnera) recenzowanej książki, żadna z powyższych,

J. Hayward, British Approaches to Politics: The Dawn of a Self-Deprecating Discipline, [w:] The British Study of Politics in the Twentieth Century, red. tenże, B. Barry, A. Brown, Oxford 1999, za: C. Hay, Political Analysis. A Critical Introduction, Basingstoke 2002, s. 54.

2 J. Bartkiewicz, Dziatania prognostyczne w polityce zagranicznej (metodologia i implementacja), „Sprawy Międzynarodowe" 2007, nr 4, s. 183. 
„zachowawczych” taktyk wobec prognozowania przyszłość nie jest właściwa. Przeciwnie - w prognozach trzeba stosować jasno sprecyzowane wyrażenia i horyzonty czasowe. Trzeba stosować liczby [...] musimy [też - B.S.] posiadać wiele prognoz (s. 76). Ponadto autorzy prześmiewczo zauważają: umieść na prognozie jaką́ liczbę, a ryzykujesz, że zostaniesz nieuczciwie oskarżonym. Trzymaj się sformutowań równie konkretnych, co deszczowa chmura, a będziesz bezpieczny (s. 269). Ich zdaniem, tylko prowadząc refleksję nad metodami i technikami wykorzystywanymi w celu formułowania prognoz, można rozwijać wiedzę o ich tworzeniu, i tylko popełniając błędy, można udoskonalać własne prognozy. Podejście takie jest w dużej mierze bliskie popperowskiej wizji wiedzy naukowej, która zakłada, że tylko kolejne akty refutacji umożliwiają doskonalenie teorii naukowych.

Teoria, jeśli ma nosić miano naukowej ${ }^{3}$, musi dysponować metodą umożliwiającą formułowanie prawdziwych twierdzeń na temat przyszłych stanów. Teoria naukowa musi bowiem spełniać cztery funkcje: deskrypcyjną, wyjaśniającą, ma również dostarczać praktycznych rozwiązań i sądów wartościujących oraz dawać możliwość prognozowania $^{4}$. Ponieważ przyszłości (liczba mnoga) ontologicznie nie istnieją, dlatego w przypadku nauk humanistycznych i społecznych sprostanie ostatniemu wymogowi wiedzy naukowej jest szczególnie kontrowersyjne. Formułowanie jakichkolwiek opinii na temat przyszłości jest obarczone bardzo dużym ryzykiem popełnienia błędu, pomimo to jednak nie sposób prowadzić działalności biznesowej albo osiągać celów politycznych bez odwołania się właśnie do wiedzy o przyszłości. Nie wchodząc już w tym miejscu w różnice teoretyczne pomiędzy metodologią nauk nomotetycznych a idiograficznych, za autorami Superprognozowania... należy zauważyć, iż wyzwanie stanowi nie tylko sam fakt immanentnej (chyba) niedoskonałości nauk społecznych w zakresie prognozowania, ale problemem jest również brak odpowiedniego przygotowania w zakresie myślenia o przyszłości i warsztatu analitycznego.

Otóż właśnie sposób myślenia o przyszłości jest głównym wątkiem recenzowanej książki, stąd nie mogą dziwić liczne odwołania m.in. do prac z zakresu ekonomii behawioralnej, w tym Daniela Kahnemana ${ }^{5}$. Śmiało można powiedzieć, że omawiana pozycja stanowi zwieńczenie wcześniejszych badań Tetlocka, który polskim czytelnikom powinien być znany z wydanej w 2005 r. głośnej książki Expert Political Judgment. How Good Is It? How Can We Know? ${ }^{6} \mathrm{~W}$ tej pozycji zaproponował on podział ekspertów, ze względu na stosowane przez nich strategie heurystyczne, na dwa typy: lisy

W tym punkcie warto przypomnieć o stanowisku postpozytywistycznym, które w większości kwestionuje samo pojęcie wiedzy naukowej, jako w sposób nieuprawniony uprzywilejowanego sposobu opisywania świata. Poniższa recenzja pozostaje w obrębie pozytywistycznego postrzegania rzeczywistości społecznej.

4 Zob. B. Krauz-Mozer, Teorie polityki. Zatożenia metodologiczne, Warszawa 2005, s. 18-32, 76-79, 106.

5 Zob. np. D. Kahneman, Putapki myślenia. O myśleniu szybkim i wolnym, przeł. P. Szymczak, Poznań 2012.

6 P.E. Tetlock, Expert Political Judgment. How Good Is It? How Can We Know?, Princeton 2005. 
i jeże. Rozróżnienie to, zapożyczone z eseju Isaiaha Berlina ${ }^{7}$, pozwala wyróżnić dwa sposoby myślenia. Jak piszą autorzy Superprognozowania...: lis wie wiele różnych rze$c z y, z a$ to jeż wie rzecz jedna, ale wielka (s. 86). Innymi słowy, ekspert-jeż to osoba, która wierzy w jedną teorię, za pomocą której próbuje objaśnić każde zjawisko, ekspert-lis w swoich dociekaniach jest bardzo ostrożny i mniej chętnie daje się przekonać jednemu uniwersalnemu wyjaśnieniu. Wracając do otwierającej obserwacji, Tetlock zdaje się ją potwierdzać, wskazując, że istnieje odwrotna korelacja między popularnością medialną ekspertów a dokładnością ich prognoz. Wynikać to ma z faktu, iż media podążają za jasnym, mocnym i charyzmatycznym przekazem, a nie charakteryzującą ekspertów-lisy zniuansowaną, uwzględniającą różne stopnie prawdopodobieństwa rzeczową analizą (s. 88).

Interesująca jest metodologia stojąca za ustaleniami autorów Superprognozowania... Wskazówki do ulepszenia jakości warsztatu prognostycznego autorzy zbierali, obserwując przez ponad trzy lata (od września 2011 do czerwca 2015 r.) praktyki poznawcze ponad 20 tys. osób biorących udział w projekcie badawczym i formułujących swoje prognozy w ramach platformy online Good Judgment Project ${ }^{8}$. Celem eksperymentu była obserwacja sposobu postępowania i analiza heurystyk stosowanych przez uczestników, z których każdego poproszono o przygotowanie ponad 800 prognoz. W trakcie całego badania obserwowano zarówno ich indywidualną, jak i grupową pracę oraz sposób gromadzenia i przetwarzania informacji. Dzięki temu udało się wyodrębnić finalną grupę 260 tzw. superprognostów9 - ludzi, których prognozy było o 30\% trafniejsze niż prognozy pozostałych uczestników, w tym zawodowych analityków posiadających dostęp do informacji niejawnych. Wynikiem badania jest lista, w sumie jedenastu, jak określili to sami autorzy przykazań dla ambitnych superprognostów (s. 287-294).

Wątek przewodni książki nie skupia się bowiem na teoretyzowaniu myślenia o przyszłości czy roztrząsaniu wyższości jednego paradygmatu nad innym, stara się zaś ustalić i dostarczyć czytelnikowi reguły skutecznego prognozowania. Jak zauważają autorzy, przewidywanie przyszłości nie jest jakimś cudownym darem otrzymanym przy urodzeniu. Jest to efekt konkretnego sposobu myślenia, zbierania informacji oraz weryfikacji przekonania (s. 34). Większość rekomendacji to w istocie pytania skierowane bezpośrednio do czytelnika, na które sam musi znaleźć odpowiedź. Z pewnością pomocą w tym procesie będzie służyć cała książka, której nie sposób sprowadzić do poniższej listy jedenastu przykazań.

Po pierwsze, autorzy radzą, aby starannie dobierać przypadek, który ma być przeanalizowany i na temat którego ma zostać sformułowana prognoza. Istnieją bowiem sytuacje, w których rzetelna prognoza nie jest możliwa. Paula Saffo, prognosta

Który z kolei powoływał się na starożytnego greckiego poetę Archilocha.

8 Projekt został przekształcony m.in. w otwartą platformę Good Judgment Open. Zob. [online] https:// www.gjopen.com/.

9 Wywiad z grupą superprognostów można obejrzeć na: Superforecaster Full Video, YouTube, 26 II 2016, [online] https://www.youtube.com/watch?v=6POQjSjIXWk, 26 II 2016. 
technologiczny, w swoim artykule określa tę zasadę wprost - wiedz, kiedy nie prognozować ${ }^{10}$. Przykładem takiego typu jest np. (daremne) poszukiwanie w 2017 r. odpowiedzi na pytanie, kto wygra wybory prezydenckie w USA w 2028 r. Druga rada sugeruje wykorzystać strategię poznawczą Enrico Fermiego, tzn. by rozkładać pozornie nierozwiązywalny problem na jego rozwiązywalne, mniejsze części składowe, o których dysponujemy pewniejszą wiedzą. Przywołany w książce przykład pytania „ilu jest stroicieli fortepianów w Chicago?” (s. 126-130) można rozbić na co najmniej cztery pomniejsze pytania, np. ile jest fortepianów w Chicago?, ile razy do roku się stroi fortepian?, ile zajmuje strojenie fortepianu?, ile godzin rocznie pracuje przeciętny stroiciel fortepianów ? Dzięki takiemu rozbiciu trudnego pytania na mniejsze elementy możliwe staje się udzielenie przybliżonej odpowiedzi, a nie zgadywanie w ciemno. Rada trzecia podpowiada, że progności muszą posiadać zdolność do poszukiwania sytuacji analogicznych $\mathrm{z}$ analizowanym przypadkiem, by $\mathrm{w}$ ten sposób doprecyzowywać prawdopodobieństwo. Po czwarte, należy znaleźć złoty środek między nadmierną, a zbyt słabą reakcją na dowody. Nowe fakty bardzo często zbyt pochopnie są wkomponowywane w już istniejącą prognozę, zazwyczaj potwierdzając ją. Piąte przykazanie wskazuje, że: sformutowanie „być może” niewiele mówi, tak naprawdę. Dlatego twój wskaźnik niepewności musi posiadać więcej niż trzy pozycje. Niuanse mają duże znaczenie. Im więcej stopni niepewności potrafisz rozróżnić, tym lepszym prognosta masz szansę zostać (s. 291). Siódma rada mówi o utrzymywaniu w procesie tworzenia prognozy równowagi pomiędzy niedostateczną a nadmierną pewnością siebie odnośnie do prawdziwości gromadzonych faktów. Ósme przykazanie superprognosty zachęca do uczenia się na własnych błędach i sukcesach oraz by w tym procesie szczególnie uważać na błędy pewności wstecznej, objawiające się tym, że jak tylko poznamy wyniki jakiegoś wydarzenia, wiedza ta znieksztatca aktualny obraz naszych wcześniejszych ocen, których dokonalismy przed poznaniem wyni$k u$ (s. 196). Innymi słowy, post factum, już po zajściu jakiegoś wydarzenia wydaje się ono bardziej prawdopodobne niż uprzednio. Dziewiąte przykazanie odnosi się do konieczności opanowania przez prognostów sztuki pracy w zespole i zarządzania nim. Przedostatnia rekomendacja mówi o refleksyjnym uczeniu się sztuki prognozowania przez pogłębioną i świadomą praktykę. Jedenaste przykazanie jasno wskazuje, by powyższych dziesięciu przykazań nie traktować jak przykazań.

$\mathrm{Z}$ pewnością Superprognozowanie... jest pozycją, która stanowi uzupełniający i ważny głos w debatach na temat metodologii nauk społecznych, zwłaszcza politologii i stosunków międzynarodowych. Jej wartość polega na opisaniu prognostyki z innego, świeżego w polskim kontekście punktu widzenia. Opierając się na poważnych badaniach, autorom udało się zaproponować katalog dobrych praktyk, wartych zastosowania w pracy analitycznej. Co interesujące, uczynili to bez odwoływania się do debat międzyparadygmatycznych, geoekonomii czy geopolityki. Po prostu potraktowali predykcyjną funkcję teorii w sposób bardzo praktyczny i techniczny i właśnie z tego powodu książka autorstwa Philipa E. Tetlocka i Dana Gardnera warta jest lektury.

10 P. Saffo, Sześć zasad efektywnego prognozowania, „Harvard Busisess Review Polska” 2008, nr 60, s. 101 $-102$. 
Z pewnością powinny po nią sięgnąć osoby zajmujące się analizą informacji i tworzące analizy na potrzeby naszego państwa.

\section{BIBLIOGRAFIA}

Bartkiewicz J., Dziatania prognostyczne w polityce zagranicznej (metodologia i implementacja), „Sprawy Międzynarodowe” 2007, nr 4.

Hay C., Political Analysis. A Critical Introduction, Basingstoke 2002.

Kahneman D., Putapki myślenia. O myśleniu szybkim i wolnym, przeł. P. Szymczak, Poznań 2012. Krauz-Mozer B., Teorie polityki. Zatożenia metodologiczne, Warszawa 2005.

Saffo P., Sześć zasad efektywnego prognozowania, „Harvard Busisess Review Polska” 2008, nr 60. Superforecaster Full Video, YouTube, 26 II 2016, [online] https://www.youtube.com/watch? $\mathrm{v}=6 \mathrm{POQjSjIXWk}$.

Tetlock P.E., Expert Political Judgment. How Good Is It? How Can We Know?, Princeton 2005. 